\title{
GRAY ECONOMY AS A PART OF TAX GAP
}

\section{DARIUSZ PAUCH}

University of Szczecin, Faculty of Management and Economics of Services, POLAND

e-mail: dariusz.pauch@wzieu.pl

\begin{abstract}
\begin{tabular}{l|l} 
RECEIVED & 3 May 2018
\end{tabular}
\begin{tabular}{l|l} 
ACCEPTED & 10 September 2018
\end{tabular}

JEL

CLASSIFICATION

$\mathrm{H} 2, \mathrm{H} 26$

KEYWORDS gray economy, tax gap

ABSTRACT The article attempts to point to the gray economy as an element of the tax gap. The considerations began with the characterization of the tax gap. Next, the concept and importance of the gray economy in the economy was analyzed. The last part includes selected instruments for reducing the gray economy, which were introduced in recent years in Poland. The instruments limiting the gray economy include: receipt lottery, electronic cash register system, limitation of cash payments and mechanisms supporting the collection of taxes.
\end{abstract}

\section{Introduction}

The literature on the subject often uses terms such as "unobserved economy", "gray market", "black market", and "tax gap" or "tax fraud" in the context of lost tax revenue. Some of these terms are often used interchangeably, although there are significant differences between them. 
Economists have been interested in the phenomenon of the "gray economy" for several decades. Researchers agree that regardless of the size of the phenomenon, it has a significant, mainly negative, impact on the economy. Estimating the real size of the gray economy is difficult, and the lack of full knowledge of sizes, the ability to indicate all the causes of existence and factors conducive to the development of the "gray economy" also makes it impossible to effectively reduce the scale or even eliminate the above- mentioned phenomenon.

Counteracting the gray economy is crucial for improving the stability and security of the State. The larger the gray economy, the bigger is the corruption, distorted competitiveness and organized criminal groups, which deliberately use legislative weaknesses or the weakness of law enforcement by law enforcement and the judiciary agencies.

The aim of the article is to show the gray market as an element of the tax gap and the presentation of instruments for reducing the gray market in Poland. Due to volume restrictions, only an outline of the functioning of the gray market reduction instruments was made.

\section{VAT gap}

Polish legislation has not defined the term of "tax gap". It is assumed that this is the difference between the value of tax revenues, which should theoretically - in line with the applicable regulations and the scale of economic activity - flow into the public finance sector and the value of actually received tax revenues. However, according to the American Internal Revenue Service, the tax gap allows to measure the scale in which taxpayers do not file tax returns and do not pay tax on time (IRS, 2018).

The gray economy (usually) increases the tax gap because it is part of the actual (though not observed) economic activity, which - in accordance with applicable regulations - should be (usually) taxed. The loss of public finance sector revenues resulting from the presence of the gray economy also includes non-tax revenues, e.g. resulting from unpaid social security contributions of unregistered employment. However, the tax gap is not generated by the black market. It is true that it also forms part of the real, though unobserved economic activity, but the transactions cover illegal products or services (e.g. drugs), which, by definition, are not taxed under the applicable law.

The tax gap is a complex phenomenon including (see Figure 1):

- so-called "Gray economy", understood as activity remaining in accordance with the law, from which, however, the amount of tax due is not paid,

- tax fraud - understood as an activity aimed, in particular, at obtaining property benefits by not paying the tax amount due,

- unpaid tax as a result of the bankruptcy of VAT taxpayers,

- lack of efficiency of the tax office in the control and collection of due taxes, which were disclosed to the tax administration,

- activities aimed only at reducing the liability by means of legal measures but in a way inconsistent with the legislator's intention, i.e. tax avoidance.

Tax evasion occurs across the EU, leading to significant losses in budget revenues, breaches of the principle of fair taxation as well as distortion of competition conditions (NIK, 2016). 


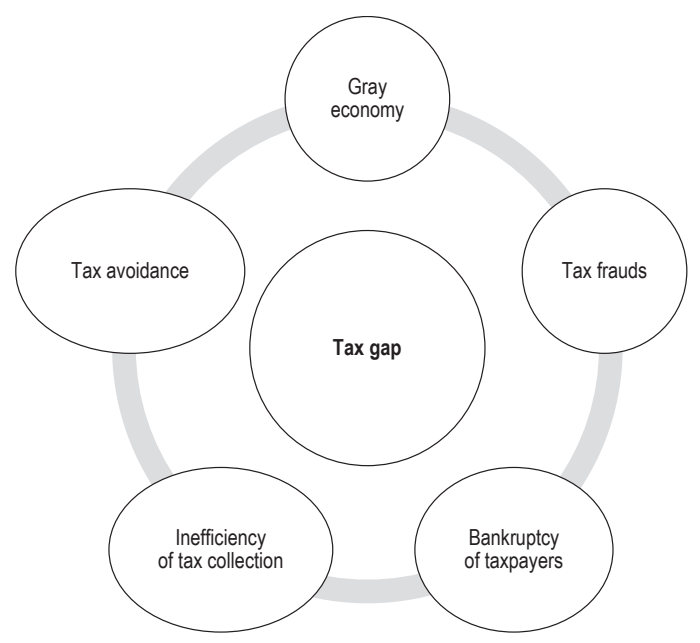

Figure 1. Elements of tax gap

Source: PWC (2017).

According to Case report (CASE, 2017) prepared for the European Commission, which estimates the size of the VAT gap in individual countries, Poland is characterized by a high level of VAT gap as in 2015 it amounted to $24.5 \%$ of theoretical inflows, exceeding the average for the EU countries by 10 percentage points. However, according to the estimates of PricewaterhouseCoopers, the size of the tax gap in the last two years was to be reduced. The actions taken by the Ministry of Finance to limit VAT fraud in Poland were to contribute to this. The examples of instruments are presented in the further part of the article.

\section{The concept and significance of gray economy}

The ambiguity of this concept is demonstrated by the multitude of terms functioning in professional literature and in the media. The terms such as gray economy, black economy, underground economy, sub-economy economy, secondo economy, shadow, informel, irregular, parallel economy are often used interchangeably. The fact that all these terms can be found in the world literature means that this phenomenon is permanent and exists in all economies (Krajewska, 1998).

The basic definition defines the "gray economy" as any economic activity that contributes to the official (or observable) GDP, but which remains directly unregistered (Schneider, Enste, 2000). Another definition emphasizes that the "gray economy" involves such economic activities that remain unmeasured or are not reported (Feige, 1979).

According to B.S. Freya and F. Schneider, gray economy is made up of all unregistered types of productive activity (creating added value) at a given time, which should be included in the national product (Frey, Schneider, 2000).

Compliance with the rules is included in the official economy, actions that break the rules are part of "gray economy". Activities belonging to the "gray economy" are then divided into groups distinguished by the type of broken rules (Cichocki, 2006): 
1. Illegal economy - consists of economic activities that violate legal provisions that determine the scope of legal economic activity. It includes, for example, the production of illegal drugs and the exchange of foreign currencies.

2. Unreported economy - consists of activities bringing income not reported to tax authorities.

3. Unrecorded economy - consists of actions not reported to the government statistical institutions.

4. Informal economy - consists of economic activities, which on the one hand avoid costs resulting from any regulations, and on the other hand are not covered by the benefits resulting from the above rules. The literature indicates the following negative aspects of the large share of the gray economy in the economy (Krajewska, 2010):

- basic economic indicators related to the economy, such as the level and dynamics of GDP, inflation, employment, are distorted - the government has therefore no good basis for conducting a rational economic policy,

- unfair competition for entities, which have higher costs because they pay taxes and social security contributions,

- a larger budget deficit resulting from lower tax revenues,

- higher interest rate resulting from the fact that in an environment of low tax collection, state bonds are an alternative form of financing public expenditure, while the increasing supply of bonds is accompanied by higher interest rates that ensure additional demand for these securities,

- weakened functioning of the social security system due to the fact that employees employed unofficially are not burdened with social security contributions,

- negative assessment of the government by the society, which is not conducive to carrying out reforms that increase the effectiveness of economic policy.

One cannot omit the fact of the benefits of the "gray economy". The positive sides of the existence of the above phenomenon include (Pater, 2007):

1. From the point of view of the economy, unrecorded work increases the labor market, although mostly jobs with low productivity and low wages are created, which would not have been created in the formal area of the economy.

2. Those employed in the gray economy are purchasers of goods and services, thus they increase consumer demand, indirectly contributing to increasing budget revenues from VAT, and to some extent also contributing to the creation of new legal jobs.

3. From the point of view of an employee, unrecorded work is a source of income, the absence of which would increase the risk of poverty for the working person and his/her family. For a certain group of employees, especially those with low qualifications, the possibility of taking up unrecorded work is in practice the only chance for their own income.

4. Employers also profit from unrecorded work. Of course, the most important benefit is lower labor cost, and sometimes this is an essential factor influencing the final decision about employing an employee. Due to administrative barriers, unrecorded employment is the only way to quickly get a job done by a short-term employee. Unrecorded employment also reduces the economic risk associated with recorded employment (e.g. financing sick absence during the first 33 days of the year). 


\section{The instruments to limit gray economy}

The following instruments that have been introduced in recent years by the state administration in Poland can be distinguished.

\section{Receipt lottery}

The receipt lottery is a mechanism addressed to consumers in Poland and is aimed at encouraging the transactions be confirmed by a receipt that plays the role of lottery ticket. Similar solutions are also used in many other countries, e.g. Portugal, Slovakia or Croatia. According to the assumptions of the lottery, it should result in an increase in the number of transactions subjected to VAT (a reduction of the VAT gap in this respect) and an increase in revenue taxed with income tax.

\section{The system of electronic cash registers}

This mechanism, already implemented in some European countries, aims at limiting the gray economy in the field of not registering transactions between the seller and the consumer. The mechanism consists in introducing the obligation to use cash registers, which automatically send data about completed transactions to the tax authorities via the electronic system. The aim of the mechanism is to increase the degree of registration of transactions carried out in the consumer turnover by providing tax authorities with information on ongoing transactions. This means that these authorities can immediately analyze and identify suspicious transactions and unjustified changes in the amount of turnover and, as a result, take appropriate action on an ongoing basis to clarify doubts and ensure tax collection.

In order to improve the efficiency of taxpayer activity control, reduce tax evasion and ensure conditions of equal competition among economic entities, the electronic cash register system is being introduced in a growing number of countries, including Bulgaria (from April 2012), Croatia (from January 1, 2013), Slovenia (from 2016). In 2013-2014 such a system was introduced in Hungary, which according to the report of the Hungarian central bank - could lead to an increase in VAT revenue in 2014 by about 150 billion forints ( $0.5 \%$ of GDP).

\section{Limitation of cash payments}

Promotion and support of the development of non-cash transactions is one of the important elements in the fight against the gray economy. In the gray economy, payments are almost exclusively made in cash, so that there are no traces of transactions in the financial system. Activities supporting non-cash transactions from the state include, for example, introducing the possibility of paying with cards in offices, which would certainly convince many consumers that card payments are convenient and safe.

Electronic payments, unlike cash payments, leave a trace in the banking system, making it difficult to hide transactions. In this way, they can be an important tool in fighting the gray economy. Therefore, in many European countries there are limits defining the maximum value of cash transactions, e.g. in settlements between entrepreneurs or between entrepreneurs and consumers. The electronic trace in settlements between entrepreneurs makes it difficult to implement illegal activities related to tax evasion, but other activities, such as money laundering, support of terrorism or acquisition of products of illegal origin are also somehow prevented. In the case of consumer transactions, electronic payments allow primarily to limit the scale of transaction non-registration and evasion 
of payment of tax due. In Poland, the mechanism of enforced non-cash transactions concerns only transactions between entrepreneurs and consists in the obligation to make or accept payments via a bank account, when the single value of the transaction exceeds the equivalent of PLN 15,0001.

\section{Systems supporting corpect tax collection}

\section{Reverse charge mechanism}

The reverse charge mechanism is a means of counteracting the occurrence of tax fraud and is mentioned as an administrative mechanism for counteracting economic crime. In Poland, the above mechanism was introduced on April 1, 2011 and was initially in force in connection with the performance of activities such as the sale of greenhouse gas emission allowances and trade in scrap metal. The reverse charge mechanism assumes that the purchaser of goods or services is obliged to settle the tax due on the activity subjected to VAT. This mechanism is an exception to the general rule, according to which the VAT settlement is made by the seller who performs the delivery of goods or provides the service (Pauch, 2017).

\section{Joint and several liability}

Joint and several liability introduced into the Polish legal system from October 1, 2013, is a measure intended to increase the effectiveness of the fight against VAT fraud by motivating taxpayers to verify their contractors, suppliers of so-called sensitive goods and securing the collection of tax resulting from transactions aimed at VAT fraud. Under this mechanism, the VAT payer is jointly and severally liable with the supplier for the tax arrears of the supplier in a proportion of the tax proportionally attributable to the delivery made to the buyer, if (Ustawa o podatku od towarów i usług, 2004):

- the value of these goods without the tax amount exceeded PLN 50,000 in the given month, and

- at the time of delivery of these goods, the taxpayer knew or had reasonable grounds to suppose that the entire amount of tax due to the delivery of these goods or part thereof to it would not be paid into the account of the tax office.

The model of joint and several liability adopted in Poland is aimed at limiting the use of the "disappearing taxpayer" mechanism and consists in imposing on the buyers of certain goods, particularly vulnerable to frauds involving VAT fraud, joint and several liability for the seller's tax liabilities. This mechanism is to have primarily a preventive function, manifesting itself in closer monitoring of the contractors by taxpayers and securing the interest of the state budget by recovering fraudulent amounts from a buyer, which is not careful enough.

\section{Split payment}

In the split payment model, the buyer of goods or services, as part of payment for a good or service, pays VAT to a bank account controlled by tax authorities, which the supplier of goods or a service provider may only use for VAT purposes and to pay VAT to tax authority. The purpose of this mechanism is to ensure that the tax for the services rendered or the sale of the goods is properly paid to the tax office. The effectiveness of this mechanism is

\footnotetext{
${ }^{1}$ The limit is effective from January 1, 2017.
} 
a result of cutting off the offenders from having the amount of due VAT and eliminating cash settlements between entrepreneurs. At the same time, this is a solution that significantly affects the financial flow of VAT taxpayers.

\section{Centrpal database monitoring VAT settlements}

This mechanism consists in creating a central register of invoices and VAT register, in which taxpayers would be obliged to generate invoices or enter invoices issued outside the register. Invoices in the register would go to buyers. The purpose of the mechanism is to provide the tax authorities with access to all invoices of the taxpayer, and as a consequence, the tax authorities would have the possibility of ongoing control of transactions. In addition, the introduction of additional IT tools would allow faster detection of anomalies and irregularities related to issued invoices. Thanks to the application of this model, tax authorities obtain direct access to data of issued invoices and the ability to perform ongoing and constant control of transactions. This favors increasing the efficiency of tax authorities by allowing them to take immediate action to prevent tax fraud, for example blocking the VAT refund, deregistering the taxpayer, initiating a tax audit, blocking bank accounts.

\section{Conclusions}

Conducting a thoughtful and effective policy in relation to unofficial forms of economic activity is not an easy task. This applies both to the conceptual stage (designing economic policy) and the implementation stage, which generally posess the greatest problems. When choosing a set of instruments for the implementation of the assumed objectives (policy mix), not only the size of the unofficial economy measured by the percentage share of GDP should be taken into account, but also its impact on income redistribution processes and the implications for micro- and macroeconomic efficiency.

Economic policy towards the gray economy should take into account many different aspects and dimensions of social and economic life. The selection of instruments for its implementation, allowing to prevent the occurrence of undesirable phenomena (e.g. in the form of uncontrolled growth of unofficial forms of economic activity) and effectively enforce existing legal regulations, should be particularly careful. The government's policy towards various types and areas of the gray economy was active and used various instruments of economic, administrative and legal methods. The instruments indicated in the article make it difficult for fraudsters to operate, but they also create additional obligations for honest taxpayers.

\section{References}

CASE (2017). Study and Reports on the VAT Gap in the EU-28 Member States: 2017 Final Report.

Cichocki, S. (2006). Metody pomiaru szarej strefy. Gospodarka Narodowa, 1-2, 37-38.

Feige, L.E. (1979). How Big Is the Irregular Economy? Challenge, November-December.

Frey, B.S., Schneider, F. (2000). Informal and Underground Economy. University of Linz Working Papers, vol. 10, p. 2.

IRS (2018). Understanding the Tax Gap. Retrieved from: https://www.irs.gov/uac/understanding-the-tax-gap, 2005 (15.03.2018).

Krajewska, A. (2010). Podatki w Unii Europejskiej. Warszawa: Polskie Wydawnictwo Ekonomiczne.

Krajewska, A. (1998). Uwarunkowania i konsekwencje szarej strefy w Polsce. In: Etyka w życiu gospodarczym, Annales, t. 1. Łódź: SWSEiZ.

NIK (2016). Przeciwdziałanie wprowadzaniu do obrotu gospodarczego faktur dokumentujących czynności fikcyjne. Nr ewid. 24/2016/P/15/011/KBF. Retrieverd from: https://www.nik.gov.pl/kontrole/P/15/011/KBF. 
Pater, K. (2007). Przyczyny pracy nierejestrowanej, jej skala, charakter i skutki społeczne. Warszawa: Ministerstwo Pracy i Polityki Społecznej. Retrieved from: https://docplayer.pl/10342433-Przyczyny-pracy-nierejestrowanej-jej-skala-charakter-i-skutkispoleczne.html.

Pauch, D. (2017). Wybrane instrumenty ograniczania oszustw podatkowych w podatku VAT. Finanse, Rynki Finansowe, Ubezpieczenia, $4(88 / 2)$.

PWC (2017). VAT fraud - tax gap in 2016 and forecast for 2017.

Schneider, F., Enste, H.D. (2000). Shadow Economies: Size, Causes and Consequence. Journal of Economic Literature, XXXVIII, March, 77-114.

Ustawa z 11.03.2004 o podatku od towarów i usług. Dz.U. nr 54, poz. 535, z późn. zm., art. 105a, ust. 1.

Cite this article aS: Pauch, D. (2018). Gray economy as a part of tax gap. European Journal of Service Management, 3 (27/1), 197-204. DOI: $10.18276 /$ ejsm.2018.27/1-24. 